\title{
Influence of Socio Demographic Factors on Health Status among Tribal and Non-tribal Mothers: Karnataka, India
}

\author{
Pooja Patil* and Sunanda Itagi
}

Department of Human Development and Family Studies, College of Community Science, University of Agricultural Sciences, Dharwad-580005

*Corresponding author

\section{A B S T R A C T}

\begin{abstract}
Aim of the present study is to investigate the influence of socio demographic factors on health status of tribal and non tribal mothers. A large and growing body of research evidence revealed that socio demographic factors significantly influenced the health status of an individual. Cross sectional survey was conducted during 2017 among Siddi and rural mothers of Uttar Kannada district, Karnataka. A total of 120 mothers in the age group of 18-50 years were interviewed out of which 60 were Siddi and 60 were rural mothers. Mothers were randomly selected and informed consent was taken to gather required information. Structured interview schedule was used to elicit personal information. Health status in terms of health problems was assessed by using PGI health questionnaire, lower the score better the health status. Socio economic status of the family was assessed with Agarwal scale. Data was analyzed with proper statistical methods. Differential design was used to know the difference in health status between rural and Siddi tribal mothers. Chi square was used to know the association of health status with age, education and socio economic status. With the help of correlation research design relation between health status and socio demographic factors were carried out. Result revealed that 50 percent of mothers were in the age group of 29- 39 years and majority of them were self employed with income less than 5000 per year. More than half of Siddi mothers were illiterate and only 13.3 of rural mothers were literate. Health status of Siddi tribal mothers were found to be better than rural mothers however it was not found significant difference. Age was not significantly associated and correlated with health status, but education was significantly influenced the health status of rural mothers only. It was observed that higher the education lower health problem.
\end{abstract}

Keywords

Health Status,

Socio-demographic, Structured

Article Info

Accepted:

04 August 2019

Available Online:

10 September 2019

\section{Introduction}

It is habitually believe that good health is vital to human welfare and is a primary objective of social and economic development. It is often believe that health status is not a term that is commonly used or instantly understood.
Perhaps in current days most of people who are frequently familiar with health care would be pretending the health status as jargon. The broad definition of health proposed by the World Health Organization (WHO) "a state of complete physical, mental and social wellbeing and not merely the absence of disease 
and infirmity." It is well standard that health is not the elite domain of medical science because every culture, irrespective of its simplicity and complexity, has its own thinking and practices concerning diseases. Health status is influenced by number of factors and it is associated with perspective aspect. To understand health and health related problems in a proper perspective, it is very important to consider the sociocultural issues, economic dimensions and environmental aspects. This is more relevant in the context of tribal people, particularly living in the rural areas.

The health status of individuals is influenced by belief systems, household decision-making to seek care, social network, economic status, age and education. Some of the factors reported by several studies that socio demographic factors significantly affect the health status of poorer households especially those in the rural areas include the availability of specialists; lack of resources and out-ofpocket financing of health-care services; sociocultural taboos and prevalence of traditional healthcare in the environment; poor access to good health-care services; and also the prevalence of traditional healthcare in the environment; educational attainment; family size; and perception of severity of illness.

India entails 8.6 per cent of total tribal population. In Karnataka, it constituted 6 percent of the population. India's poor tribal people have far worse health indicators than the general population. Most tribal people live in remote rural hamlets in hilly, forested or desert areas where illiteracy, trying physical environments, malnutrition, inadequate access to potable water, and lack of personal hygiene and sanitation make them more vulnerable to disease. For example acute diarrheal problems were basically due to poor environmental hygiene, lack of safe drinking water, improper disposal of human excreta, aggravated by low literacy, socio-economic status coupled with blind cultural belief, lack of access to medical facilities leading to serious public health problems.

Health of indigenous or tribal people is the acuity and conception in their own cultural system with less awareness of the modern health care and health sources. The different tribal communities in India, represents a heterogeneous group.

In most of the tribal communities, there are number of folklores related to health. Knowledge of folklore of different sociocultural systems of tribals may have positive impact, which could provide the model for appropriate health and sanitary practices in a given eco-system which turns to be better health status of the tribal population. Few contradictory results revealed opposite trend, study conducted by Pooja and Sunanda (2017) investigated that Siddi tribal women had lower knowledge on general health as well as reproductive health which intern it has spills over effects on their overall health. But in the true scene it evidenced that tribal people have easy accessibility to whole plants, flowers, seeds, animals and other naturally available substances formed the major basis of treatment, this practice always had a touch of mysticism, supernatural and magic, often resulting in specific magico-religious rites. With the coming to the state in the tribal areas during pre and post-independence number of changes are taking place in both material and non-material culture of tribal masses. Change in health and disease management is one among them. How tribes at large perceive health and disease today? What are the common diseases among them? Do the traditional and indigenous methods and the modern and exogenous interventions go hand in hand or there is conflict between both of them. Hence present study hope to focus on Siddi tribal primitive group of Karnataka 
which is one of the ethnic group, members are descended from Bantu peoples from Southeast Africa that, were brought to the Indian subcontinent as slaves by Portuguese merchants. There are 50,000 Siddi populations across India, of which more than a one third lives in Karnataka. In Karantaka they densely residing in Uttar kannada District. The Siddis are Roman Catholics, Hindus and Muslims. Siddis mainly speak the Kannada language. Some also speak other languages, such as Konkani and Marathi. Part of Masters Work presenting influence of socio demographic factors on health status of tribal and non tribal mothers.

\section{Materials and Methods}

The cross sectional study was carried out among rural and Siddi tribal mothers on total of 120 mothers of which 60 were rural mothers and 60 were Siddi tribal mothers, who belonged to age group of 18-49 years. The population was selected randomly from six villages of both Dharwad and Uttar Kannada districts, which consisted of 600-625 households. Data pertaining to age, occupation, educational status, type of family, number of children, caste and type of diet were collected from both rural and Siddi tribal mothers using a pretested self structured questionnaire.

Health status of the respondents was measured by using PGI scale (Wig and Verma 1978) which assesses the status of wellness, fitness and underlying diseases or injuries. It has 50 statements on 4 point likert score which ranges from 1 to 4 where 1 is given for never and 4 given for too often. Higher the score indicates more the health problems. Health problems were categorized as mild, moderate and severe health problems. Before interacting with Siddi tribal mothers' researcher has taken prior permission from local head and briefly explained about purpose of study and information is used only for study purpose. Mothers were interviewed during their free time. Participants past one month health problems were taken in to consideration for current investigation.

The differential research design was used to know the difference between health status in terms of health problems of rural and Siddi tribal mothers. Chi square was used to know the association of health status with age, education and socio economic status. Correlation design was used to know relation between health status in terms of health problems and socio demographic factors of rural and Siddi tribal mothers.

\section{Results and Discussion}

Table 1 represents personal characteristics of rural and Siddi tribal mothers which includes age, occupation, education, size of the family, no of children, type of family, caste and type of diet. In rural mothers 55.0 per cent of them belonged to $18-28$ years age group. Among Siddi tribal mothers 55.0 per cent of them belonged to 29-39 years age group. Totally half of them belonged to 29-39 years followed by 43.3 per cent were in 18-28 years and only 6.6 per cent belonged to $40-50$ years age group. Regarding the occupation of the rural mothers more than half of them $(66.7 \%)$ found to be self employed with income Rs. $<5000$ followed by service at shops, home, transport, own cultivation of land (23.3) and self employed or petty business with income Rs. > $5000(10 \%)$.While 86.6 per cent and 13.3 per cent of the Siddi tribal mothers found to be the self employed with income Rs. < 5000 and service at shops, home, transport, own cultivation of land respectively.

With respect to education of rural mothers, 31.7 per cent of them possessed education up to tenth class pass but less than graduation as well as less than primary education followed 
by primary pass but less than $10^{\text {th }}(18.3 \%)$ but in case of Siddi tribal mothers 63.4 per cent of them found illiterate followed by less than primary but attended school for at least one year of education $(16.7 \%)$. In rural mothers, 31.7 per cent of them possessed education up to tenth class pass but less than graduation as well as less than primary education followed by primary pass but less than $10^{\text {th }}(18.3 \%)$,
Illiterate $(13.3 \%)$ and just literate but no schooling $(5.0 \%)$. In case of Siddi tribal mothers 63.4 per cent of them found illiterate followed by less than primary but attended school for at least one year of education (16.7 $\%)$, just literate but no schooling $(8.3 \%)$, primary pass but less than graduation $(6.7 \%)$ and tenth class pass but less than graduation level of education $(5.0 \%)$.

Table.1 Personal characteristics of rural and Siddi tribal mothers

\begin{tabular}{|c|c|c|c|c|}
\hline & & & & $\mathbf{N}=\mathbf{1 2 0}$ \\
\hline Sl. No. & Variables & $\begin{array}{c}\text { Rural } \\
(\mathbf{n}=\mathbf{6 0})\end{array}$ & $\begin{array}{c}\text { Siddi } \\
(\mathrm{n}=60)\end{array}$ & $\begin{array}{l}\text { Total } \\
\quad=160)\end{array}$ \\
\hline I & Age (years) & & & \\
\hline & $18-28$ & $\begin{array}{c}33 \\
(55.0)\end{array}$ & $19(31.7)$ & $52(43.3)$ \\
\hline & 29-39 & $\begin{array}{c}27 \\
(45.0)\end{array}$ & $33(55.0)$ & $60(50.0)$ \\
\hline & $40-50$ & - & $8(13.3)$ & $8(6.6)$ \\
\hline II & Occupation & & & \\
\hline & $\begin{array}{l}\text { Service in central/State/Public undertakings or Owner of a } \\
\text { company employing }>20 \text { persons or self employed } \\
\text { professional }\end{array}$ & - & - & - \\
\hline & $\begin{array}{l}\text { Service in Private sector or independent business } \\
\text { employing 2-20 persons }\end{array}$ & - & - & - \\
\hline & Service at shops, home, transport, own cultivation of land & $\begin{array}{c}14 \\
(23.3)\end{array}$ & $8(13.3)$ & $22(18.73)$ \\
\hline & Self employed or petty business with income $>5000$ & $6(10)$ & - & $6(5)$ \\
\hline & Self employed with income <5000 (labourer, house wife) & $\begin{array}{c}40 \\
(66.7)\end{array}$ & $52(86.6)$ & $92(75.8)$ \\
\hline & None of the family member is employed & - & - & - \\
\hline III & Education & & & \\
\hline & $\begin{array}{l}\text { Professional qualification with technical degree or } \\
\text { diplomas. }\end{array}$ & - & - & - \\
\hline & Post graduation & - & - & - \\
\hline & $10^{\text {th }}$ class pass but $<$ Graduation & $\begin{array}{c}19 \\
(31.7)\end{array}$ & $3(5.0)$ & $22(18.3)$ \\
\hline & Primary pass $<10^{\text {th }}$ & $\begin{array}{c}11 \\
(18.3)\end{array}$ & $4(6.7)$ & $15(12.5)$ \\
\hline & $<$ primary but attended school for at least one year & $\begin{array}{c}19 \\
(31.7)\end{array}$ & $10(16.7)$ & $29(24.2)$ \\
\hline & Just literate but no schooling & $3(5.0)$ & $5(8.3)$ & $8(6.7)$ \\
\hline & Illiterate & $8(13.3)$ & $38(63.4)$ & $46(38.3)$ \\
\hline
\end{tabular}




\begin{tabular}{|c|c|c|c|c|}
\hline IV & Size of the family & & & \\
\hline & $<5$ & $34(56.7)$ & $27(45.0)$ & $61(50.8)$ \\
\hline & $6-8$ & $20(33.3)$ & $28(46.7)$ & $48(40.0)$ \\
\hline & $>8$ & $6(10.0)$ & $5(8.3)$ & $11(9.16)$ \\
\hline V & No of children & & & \\
\hline & $0-1$ & $2(3.3)$ & - & $2(1.7)$ \\
\hline & 2 & $21(35.0)$ & $7(11.7)$ & 28 \\
\hline & 3 & $25(41.7)$ & $26(43.3)$ & $51(42.5)$ \\
\hline & 4 & $6(10.0)$ & $13(21.7)$ & $19(15.8)$ \\
\hline & 5 & $4(6.7)$ & $10(16.7)$ & $14(11.7)$ \\
\hline & $>6$ & $2(3.3)$ & $4(6.7)$ & $6(5.0)$ \\
\hline VI & Type of family & & & \\
\hline & Nuclear & $36(60.0)$ & $47(78.3)$ & $83(69.2)$ \\
\hline & Joint & $24(40.0)$ & $13(21.7)$ & $37(30.8)$ \\
\hline VII & Caste & & & \\
\hline & Upper caste & $43(71.7)$ & - & $43(35.8 .3)$ \\
\hline & $\mathrm{OBC}$ & $6(10.0)$ & - & $6(5.0)$ \\
\hline & Dalits & $11(18.3)$ & - & $11(18.33)$ \\
\hline & Tribals & - & $60(100.0)$ & $60(50.0)$ \\
\hline VII & Type of diet & & & \\
\hline & Vegetarian & $22(36.7)$ & $11(18.3)$ & $33(27.5)$ \\
\hline & Non vegetarian & $33(55.0)$ & $49(81.3)$ & $82(68.3)$ \\
\hline & Eggartarian & $5(8.3)$ & - & $5(4.2)$ \\
\hline
\end{tabular}

Figures in the parenthesis indicate percentage 
Table.2 Marital characteristics of rural and Siddi tribal mothers

$$
\mathbf{N}=\mathbf{1 2 0}
$$

\begin{tabular}{|c|c|c|c|c|}
\hline Sl. No & Variables & $\begin{array}{l}\text { Rural mothers } \\
\quad(\mathbf{n}=\mathbf{6 0})\end{array}$ & $\begin{array}{c}\text { Siddi } \\
\text { Mothers } \\
(\mathbf{n}=\mathbf{6 0})\end{array}$ & $\begin{array}{l}\text { Total }(\mathrm{N}= \\
120)\end{array}$ \\
\hline \multirow[t]{6}{*}{ I } & \multicolumn{4}{|l|}{ Age at marriage (years) } \\
\hline & $\leq 12$ & - & $6(10.0)$ & $6(5.0)$ \\
\hline & $13-14$ & $3(5.0)$ & $10(16.7)$ & $13(10.8)$ \\
\hline & $15-16$ & $11(18.3)$ & $18(30.0)$ & $29(24.2)$ \\
\hline & $17-18$ & $22(36.7)$ & $15(25.0)$ & $37(30.8)$ \\
\hline & $>18$ & $24(40.0)$ & $11(18.3)$ & 35 (29.2) \\
\hline \multirow[t]{3}{*}{ II } & \multicolumn{4}{|l|}{ Type of marriage } \\
\hline & Consanguineous & $24(40)$ & $28(46.7)$ & $52(43.3)$ \\
\hline & Non consanguineous & $36(60)$ & $32(53.3)$ & $68(56.7)$ \\
\hline \multirow[t]{5}{*}{ III } & \multicolumn{4}{|l|}{ Parity } \\
\hline & $1-2$ & $19(31.7)$ & $2(3.3)$ & $21(17.5)$ \\
\hline & $3-4$ & $35(58.3)$ & $36(60.0)$ & $71(59.2)$ \\
\hline & $5-6$ & $6(10.0)$ & $19(31.7)$ & $25(20.8)$ \\
\hline & $7-8$ & - & $3(5.0)$ & $3(2.5)$ \\
\hline \multirow[t]{4}{*}{ IV } & \multicolumn{4}{|c|}{ Age at first pregnancy (Years) } \\
\hline & $\leq 18$ & $19(31.7)$ & $42(70.0)$ & $61(50.8)$ \\
\hline & $19-22$ & $38(63.3)$ & $15(25.0)$ & $53(44.2)$ \\
\hline & $23-26$ & $3(5.0)$ & $3(5.0)$ & $6(5.0)$ \\
\hline \multirow[t]{3}{*}{ V } & \multicolumn{4}{|l|}{ Abortion } \\
\hline & Abortion undergone & $13(21.7)$ & $25(41.7)$ & $38(31.7)$ \\
\hline & No abortion & $47(78.3)$ & $35(58.3)$ & $82(68.3)$ \\
\hline
\end{tabular}

Table.3 Health status of rural and Siddi tribal mothers

$$
\mathbf{N}=\mathbf{1 2 0}
$$

\begin{tabular}{|c|c|c|c|c|}
\hline \multirow{2}{*}{ Mothers } & \multicolumn{3}{|c|}{ Health problems } & \multirow{2}{*}{$\chi^{2}$} \\
\cline { 2 - 4 } & Mild & Moderate & Severe & \\
\hline Rural & $8(13.3)$ & $40(66.7)$ & $12(20.0)$ & $\mathbf{9 . 0}^{*}$ \\
\hline Siddi & $18(30.0)$ & $29(48.3)$ & $13(21.7)$ & \\
\hline
\end{tabular}

\begin{tabular}{|c|c|c|}
\hline Mothers & Mean \pm SD & t-value \\
\hline Rural & $129 \pm 26.9$ & $0.47^{\mathrm{NS}}$ \\
\hline Siddi & $125 \pm 36.1$ & \\
\hline
\end{tabular}

Figures in the parenthesis indicate percentage. 
Table.4 Relationship between health problems and socio economic status of rural and tribal mothers

$$
\mathbf{N}=\mathbf{1 2 0}
$$

\begin{tabular}{|c|c|c|c|c|c|c|c|}
\hline \multirow[t]{2}{*}{ Mothers } & \multirow[t]{2}{*}{ SES } & \multirow[b]{2}{*}{$\mathbf{n}$} & \multicolumn{3}{|c|}{ Health problems } & \multirow[t]{2}{*}{ Modified $\chi^{2}$} & \multirow[t]{2}{*}{ r-value } \\
\hline & & & Mild & Moderate & Severe & & \\
\hline \multirow[t]{2}{*}{ Rural } & Lower middle & 19 & $4(21.1)$ & $13(68.4)$ & $2(10.5)$ & \multirow[t]{2}{*}{$2.95^{\mathrm{NS}}$} & \multirow[t]{2}{*}{$-0.30 *$} \\
\hline & Poor & 41 & $4(9.8)$ & $27(65.9)$ & $10(24.4)$ & & \\
\hline \multirow[t]{2}{*}{ Siddi } & Poor & 11 & $6(54.5)$ & $4(36.4)$ & $1(9.1)$ & \multirow[t]{2}{*}{$4.08^{\mathrm{NS}}$} & \multirow[t]{2}{*}{$-0.23^{\mathrm{NS}}$} \\
\hline & Very poor & 49 & $12(24.5)$ & $25(51.0)$ & $12(24.5)$ & & \\
\hline
\end{tabular}

Figures in the parenthesis indicate percentage

*Significant at 0.05 level NS - Non-significant

Table.5 Relationship between health problems and age of rural and Siddi tribal mothers

\begin{tabular}{|c|c|c|c|c|c|c|c|}
\hline \multirow{3}{*}{ Mothers } & \multirow{3}{*}{$\begin{array}{l}\text { Age } \\
\text { (yrs) }\end{array}$} & \multirow[b]{3}{*}{$\mathbf{n}$} & & & & \multicolumn{2}{|c|}{$\mathrm{N}=120$} \\
\hline & & & \multicolumn{3}{|c|}{ Health problems } & \multirow{2}{*}{$\chi^{2}$} & \multirow{2}{*}{$\begin{array}{l}\text { r- } \\
\text { value }\end{array}$} \\
\hline & & & Mild & Moderate & Severe & & \\
\hline \multirow[t]{2}{*}{ Rural } & $18-28$ & 33 & $5(15.2)$ & $21(63.6)$ & $7(21.2)$ & \multirow[t]{2}{*}{$0.74^{\mathrm{NS}}$} & \multirow[t]{2}{*}{$0.17^{\mathrm{NS}}$} \\
\hline & $29-39$ & 27 & $4(11.5)$ & $18(69.2)$ & $5(19.2)$ & & \\
\hline \multirow[t]{3}{*}{ Siddi } & $18-28$ & 19 & $7(36.8)$ & $8(42.1)$ & $4(21.1)$ & \multirow{3}{*}{$2.16^{\mathrm{NS}}$} & \multirow{3}{*}{$\begin{array}{l}- \\
0.02^{\mathrm{NS}}\end{array}$} \\
\hline & $29-39$ & 33 & $9(27.3)$ & $18(54.5)$ & $6(18.2)$ & & \\
\hline & $40-50$ & 8 & $2(25.0)$ & $3(37.5)$ & $3(37.5)$ & & \\
\hline
\end{tabular}

Figures in the parenthesis indicate percentage. NS - Non-significant

Table.6 Relationship between health problems and education of rural and Siddi tribal mothers

\begin{tabular}{|c|c|c|c|c|c|c|c|}
\hline \multirow{3}{*}{ Mothers } & \multirow[b]{3}{*}{ Education } & \multirow[b]{3}{*}{$\mathbf{n}$} & & & & \multicolumn{2}{|c|}{$\mathrm{N}=120$} \\
\hline & & & \multicolumn{3}{|c|}{ Health problems } & \multirow{2}{*}{$\begin{array}{c}\text { Modified } \\
\chi^{2}\end{array}$} & \multirow[t]{2}{*}{ r-value } \\
\hline & & & Mild & Moderate & Severe & & \\
\hline \multirow[t]{4}{*}{ Rural } & Illiterate & 8 & $0(0)$ & $5(62.5)$ & $3(37.5)$ & \multirow[t]{4}{*}{$15.3^{*}$} & \multirow[t]{4}{*}{$-0.12^{\mathrm{NS}}$} \\
\hline & Primary & 25 & $4(16.0)$ & $20(80.0)$ & $1(4.0)$ & & \\
\hline & High school & 16 & $3(18.8)$ & $11(68.8)$ & $2(12.5)$ & & \\
\hline & College & 11 & $1(9.1)$ & $4(36.4)$ & $6(54.5)$ & & \\
\hline \multirow[t]{3}{*}{ Siddi } & Illiterate & 38 & $10(26.3)$ & $20(52.6)$ & $8(21.1)$ & \multirow[t]{3}{*}{ 9.07* } & \multirow[t]{3}{*}{$-0.03^{\mathrm{NS}}$} \\
\hline & Primary & 19 & $8(42.1)$ & $7(36.8)$ & $4(21.1)$ & & \\
\hline & High school & 3 & - & $2(66.7)$ & $1(33.3)$ & & \\
\hline
\end{tabular}

Figures in the parenthesis indicate percentage.

*Significant at 0.05 level NS - Non-significant. 
The marital characteristics of rural and Siddi tribal mothers are presented in the table 2 . With respect to age at marriage 40.0 per cent of the rural mothers married $>18$ years of age followed by $17-18$ years $(36.7 \%)$, but in case of Siddi tribal mothers 30 per cent of them married at 15- 16 years of age followed by $17-18$ years $(25.0 \%),>18$ years $(18.3 \%)$. There was high significant difference was observed in the age at marriage of rural and Siddi tribal mothers, where mean scores of rural mothers $(18.0 \pm 2.15)$ is higher than Siddi tribal mothers $(16.2+2.7)$

Regarding the type of marriage 40 per cent and 46.7 per cent of rural and Siddi tribal mothers respectively had consanguineous type of marriage followed by $60.0 \%$ and 53.3 $\%$ had non consanguineous type of marriage. With respect to Siddi tribal mothers more than half of them $(60.0 \%)$ experienced 3-4 times of pregnancy followed by 5-6 times (31.7), 7 8 times $(5.0 \%)$ and very few $(3.3 \%)$ experienced 1-2 times of pregnancy. With respect to age at first pregnancy 70.0 per cent of them conceived at $\leq 18$ years of age followed by 19-22 years (25.0\%) and 23-26 years of age (23-26). Mean age at first pregnancy of rural mothers $(19.5 \pm 2.1)$ higher than Siddi tribal mothers $(17.7 \pm 2.64)$. It was observed that, significant difference was found between rural and Siddi tribal mothers with respect to age at first pregnancy. Regarding abortion 78 per cent and 58.3 per cent of rural and Siddi tribal mothers respectively had not undergone abortion followed by 21.7 per cent and 41.3 per cent had experienced abortion. Similar trends was seen in overall results indicating that, more than half of the mothers (68.35) have not undergone abortion followed by experienced abortion $(31.7 \%)$. Related to type of delivery majority of Siddi tribal mother's had undergone normal type delivery $(88.53 \%)$ followed by caesarean $(11.0 \%)$ and more than half of them delivered at home $(64.4 \%)$ followed by hospital (35.5\%).
With respect to health status between rural and Siddi tribal mothers, no significant difference was observed but it was noteworthy that, cent per cent of the mothers had at least moderate health problems (Table 3). It may be because of rural mothers considered variations in health condition as a health problem and Siddi mothers were not bothered about slight variations in the health conditions as a health problems. Similar results were found by Kadankuppe and Bhat (2013) who revealed that, prevalence of disease among tribal people comparatively lower than other people.

Huge and growing research on tribal areas revealed that illness, health problems and the consequent management of disease is not always an individual or familial affair, but sometimes the decision about the nature of treatment is taken at the community level. Any slight change in their health condition leading them to take immediate remedies which is easily available from the natural resources gets natural treatment. In the tribal areas, in case of some specific diseases, not only the diseased person or his/her family, but the total village community is affected. All the other families in the village are expected to observe certain taboos or norms and food habits. Faith healing has always been a part of the traditional treatment in the Tribal Health Care System, which can be equated with rapport or confidence building in the modern treatment procedure. Certain practices are suggested to avoid illness or diseases, while some are prescribed to have better health. These should not be ignored as mere folkbeliefs, but need careful attention.

Relationship between health problems and socio economic status (SES) of rural and Siddi tribal mothers are indicated in the table 4. Rural mothers belonging to poor class of socio economic status showed that, 65.9 per cent of them exhibited moderate health problems followed by 24.4 per cent had 
severe health problems and few $(9.85 \%)$ of them showed mild health problems. Rural mothers from lower middle class of SES indicated that, 68.4 per cent of them showed moderate health problems followed by mild health problems found in 21.1 per cent of mothers and 10.5 per cent of rural mothers showed severe health problems. Siddi tribal mothers belonging to very poor class of SES pointed out that, 51.0 per cent them, exhibited moderate health problems. 24.5 per cent of the Siddi tribal mothers showed mild as well as severe health problems. It was noted that, Siddi tribal mothers from poor class of SES showed, more than half $(54.5 \%)$ them expressed mild health problems followed by moderate health problems in 36.4 per cent of mothers and very few $(9.1 \%)$ of them exhibited severe health problems.

However there was significant negative relation but no association was found between socio economic status and health problems of rural mothers (Table 4) indicated higher socio economic status lower the health problems. Dar et al. (2017) reported that, low health status is consequent upon low socio-economic status. In Siddi tribal mothers it was found non significant association and relations between SES and health problems as because, cent per cent of them belonged to very poor and poor category of socio economic status, which indicated, socio economic status is not much influencing in the health problems of the Siddi tribal mothers and though they belonged to poor and very poor category of socio economic group their health status found to better than rural mothers. Non significant association and relation found between age and health problems of rural and Siddi tribal mothers (Table 5).

However it was noticed that, as age increases the health problems also increase, it might be evident that, as the age increase their BMI also increases and decline in the biological functioning of the body, hence they are greater risk at developing more health problems.

It was observed that, there was significant association but no relation was found between education and health problems of the rural and Siddi tribal mothers (Table 6), but however it was seen that, higher the education, lesser the health problems. It might be because around 87 per cent of the rural mothers were educated (Table 1) and belonged to lower middle class of socio economic status provided opportunity to aware about health problems and to avail proper remedies for various health issues. At the same time interestingly similar trend was observed in Siddi tribal mothers between illiterate and primary class of education, where moderate health problems were decreased as increase in education Dar et al. (2017) revealed that, education and health status of the mothers were significantly associated, stated that, illiterate and primary level educated women have low health status as compared to secondary and college level of education. Dash Anjali (2013) reported that, education and health is two major dimension of economic development. Improvement of good health can be possible by improvement of education of the mothers. Study reported by Pooja and Sunanda (2017) conducted a study on Siddi tribal mothers which revealed that Siddi tribal mothers possessed lower levels of health related knowledge but study evidenced that Siddi mothers showed pretty better status with less health related problems compared to rural mothers.

Though Siddi tribal mothers had considerably fewer health problems compared to rural mothers, but few tribal and majority of rural mothers had moderate level of health problems which cannot be neglect as such, where these mothers were ignore their health a lot which appears to be major concern to take action and help them to maintain good 
health. Poor health status among mothers, were compounded by lack of awareness about the measures needed to protect their health. Lack of emergency transportation was evidenced. Villages taken in to present study were situated in densely forest; their distance from medical facilities seems to be pretty far. It was observed that, there were lack of allweather roads and affordable transportation, hence mothers finds desert in their health and ended up with acute health problems. It was elicited from the tribal mothers through interview that, insensitive and discriminatory behavior by staff at medical facilities which made them to feel down till today. Financial constraints were found to be major issues and were hit major health problems, so it needs to be tackled up immediately and needs to sensitize it.

Among Siddi tribal mothers, the association and relationship between health status and socio economic status was found to non significant. However lower SES, more the health problems was evidenced in rural mothers only. Majority of the tribal mothers married and delivered when are less than 18 years of age, so educational awareness to be plan and focused on health status of the mothers. Tribal population needs to be upgraded by bringing health care services to remote populations, raising awareness of health issues and improve their accessibility to primary health care. Without awareness of health issues, most of the populations tend to fall ill very frequently and wait too long before seeking medical help, or are referred too late by untrained village practitioners. Health awareness campaigns are necessary to bring significant investments over long periods of time for noticeable impact. Well planned efforts to bring health care of the poor, through outreach camps and mobile health units which bring desired impact. Employing health workers from tribal communities and changing the behavior of the medical staff is very much necessary, which prevent the tribal people from feeing down themselves. As tribal populations finds, it is difficult to navigate through the complexities of medical facilities, Tribal Counselors are seems to be good for them to approach. We have been feeling proud that, for the first time in Karnataka, tribal ANMs were recruited and trained to bring health care closer to tribal settlements. Such ANMs should work efficiently in the research area for the betterment of people. It was found better to start up Citizens Help Desk which provides round-the-clock assistance to tribal and other vulnerable groups in selected district and taluk level hospitals. Providing Financial Support from the part of Government seems to be very huge positive impact to mothers. While most innovations have included the provision of free medical services to poor tribal populations which leads to quality life.

\section{References}

Dar, T. A., Bharathiraja, D., Pandit, 2017, A comparative study on nutritional and health status of tribal and non-tribal reproductive women in anantnag district, jammu and Kashmir. International journal for innovative research in multidisplinary field, 3(2): 146-159.

Dash Anjali, 2013, Relates on Tribal Education and Health: Evidence from Rural Odisha, India, Int. Res. J. Social Sci., 2(11): 11-16.

Kadanakuppe, S. and Bhat, P. K., 2013, Oral health status and treatment needs of Iruligas at Ramanagara District, Karnataka, India. West Indian Med. J., 6: $73-80$

Pooja and Sunanda, 2017, Knowledge on Reproductive Health of Tribal and Non Tribal (Rural) Mothers. Int. J. Pure App. Biosci. 6 (6): 1079-1086.

Wig, N. N. and Verma, S. K., 1978, Post 
Graduate Institute of Medical Education and Res., Agra Psychol. Res. Cell, Tiwari Kothi, Agra (India).

World Health Organization, 2015, Highlights of 2015, Department of Reproductive Health and Research including special program of Research, Development and Research Training in Human Reproduction (HRP) Geneva: 1-2
World Health Organization (WHO), 2011, Hemoglobin concentrations for the diagnosis of anaemia and assessment of severity. Vitamin and mineral nutrition information system. Geneva.

World Health Organization, 1986, Health promotion: A discussion document on the concept and principles. Health Promotion, 1(1): 73-76.

\section{How to cite this article:}

Pooja Patil and Sunanda Itagi. 2019. Influence of Socio Demographic Factors on Health Status among Tribal and Non-tribal Mothers: Karnataka, India. Int.J.Curr.Microbiol.App.Sci. 8(09): 599-609. doi: https://doi.org/10.20546/ijcmas.2019.809.072 